\title{
Texture analysis is a useful tool to characterize the cutaneous biomechanical profile
}

\author{
A análise de textura é uma ferramenta útil para caracterizar o perfil biomecânico cutâneo
}

\author{
Henrique Silva ${ }^{1,2}$, Francisco Rego ${ }^{3}$, Rafaela Francisco ${ }^{2}$, L. Monteiro Rodrigues ${ }^{1,2}$ \\ ${ }^{1}$ U Lusófona, School of Health Sc \& Technologies, CBiOS (Research Center for Biosciences and Health Technologies), \\ Campo Grande 376, 1749-024, Lisboa, Portugal \\ ${ }^{2} \mathrm{U}$ Lisboa, Faculty of Pharmacy, Pharmacol. Sc Depart - Lisboa, Portugal \\ ${ }^{3} \mathrm{U}$ Lisboa, Instituto Superior Técnico, Institute for Systems and Robotics (ISR), Lisboa, Portugal \\ Email: henrique.silva@ulusofona.pt
}

\begin{abstract}
Skin displays viscoelastic properties, which allow it to sustain deformation in virtually all directions without breaking. Most devices to quantify viscoelasticity suffer from the drawback of assessing only a limited range of angles. Cutiscan ${ }^{\circledR}$ CS 100 is a recently introduced device that allows quantification of skin viscoelasticity by creating skin suction and recording the consequent displacement in a video. Displacement videos (baseline $0.50 \mathrm{~s}$; suction $-0.50-2.50 \mathrm{~s}$; recovery $-2.50-3.00 \mathrm{~s})$ of ten female subjects $(24.5 \pm 6.2$ y.o.) were obtained on the volar surface of the forearm after informed written consent. Videos were decomposed into their corresponding frames, of which a region of interest was selected and several texture analysis (TA) parameters were calculated entropy, contrast, correlation, energy, homogeneity. During suction entropy and correlation increased significantly, while energy decreased significantly. Contrast and homogeneity changed without significance. During recovery the entropy and correlation remained significantly elevated relative to baseline, suggesting that a full recovery did not take place. These results seem to confirm the usefulness of texture analysis for the purposes of skin viscoelasticity quantification based on skin displacement videos, which justifies further developments.
\end{abstract}

Keywords: skin biomechanics, Cutiscan ${ }^{\circledR}$, texture analysis, dynamic parameters

\section{Resumo}

A pele apresenta propriedades viscoelásticas, que lhe permitem sofrer deformação em praticamente todas as direcções, sem sofrer quebra. A maioria dos aparelhos de quantificação da viscoelasticidade sofrem da desvantagem de avaliar uma gama limitada de ângulos. O Cutiscan ${ }^{\circledR}$ CS 100 é um dispositivo introduzido recentemente que permite quantifica a viscoelasticidade da pele através da sucção da pele e gravação em vídeo do seu subsequente deslocamento. Foram obtidos vídeos de deslocamento da pele (basal - 0.50s; sucção - 0.50-2.50s; recuperação - 2.50-3.00s) de dez voluntários do sexo feminino (24,5 $\pm 6,2$ anos) da superfície anterior do antebraço, após consentimento informado por escrito. Os vídeos foram decompostos nas suas imagens correspondentes, nas quais foi selecionada uma região de interesse na qual foram calculados vários parâmetros de análise de textura (AT) entropia, contraste, correlação, energia, homogeneidade. Durante a sucção a entropia e correlação aumentaram significativamente, enquanto que a energia diminuiu significativamente. $\mathrm{O}$ contraste e a homogeneidade não sofreram alterações significativas. Durante a recuperação a entropia e correlação permaneceram significativamente elevadas em relação à fase basal, o que sugere que não ocorreu uma recuperação completa. Estes resultados parecem confirmar a utilidade da AT para fins de quantificação da viscoelasticidade cutânea com base em vídeos de deslocamento, o que justifica desenvolvimentos futuros.

Palavras-Chave: biomecânica cutânea, $\mathrm{Cutiscan}^{\circledR}$, análise de textura, parâmetros dinâmicos 


\section{Introduction}

Skin is the largest organ in the human body, displaying known viscoelastic properties that allow it to sustain deformation in virtually all directions without breaking (1) Skin viscoelastic properties have been investigated by a variety of methodologies over the years. Regarding testing methods, five classes can be mentioned, including tensile, torsional, indentation, impact, and elevation (by suction), with the latter receiving wider interest over the last decades. Regarding the most used quantification devices, Cutometer ${ }^{\circledR}$ operates by creating a skin suction with the consequent skin displacement being assessed by an optical system, while Reviscometer ${ }^{\circledR}$ quantifies the resonance time of transmitted skin vibrations. Both these devices suffer from the same drawback which is the limited range of angles they are able to quantify (2). The Cutiscan ${ }^{\circledR}$ CS 100 device, recently introduced, aims to modernize viscoelasticity quantification by providing a simultaneous $360^{\circ}$ angle quantification and recording it with a video camera. This video recording is constituted of a sequence of amplified photographs of the skin surface, which display a complex, irregular, and multi-patterned morphology, thereby constituting a good candidate for texture analysis (TA). TA is an analytical tool to quantify the features of a texturally rich gray-level image and has been applied in medical imaging with the purpose of improving diagnostic capacity, given that the human visual is both time-consuming and prone to misinterpretation errors (3). Until now, the quantification of Cutiscan ${ }^{\circledR}$ parameters has been performed from the analysis of $2 \mathrm{D}$ and $3 \mathrm{D}$ representations of viscoelasticity. $(2,4)$ The Cutiscan ${ }^{\circledR}$ device, despite its enormous potential, remains underexplored in terms of analytical tools, which hinder its dissemination. Our aim was to explore texture analysis of the Cutiscan ${ }^{\circledR}$ skin displacement video as an analytical tool to quantify skin viscoelasticity.

\section{Materials and Methods}

Ten female Caucasian subjects with healthy skin $(24.5$ \pm 6.2 y.o.) participated in this study after giving written informed consent. With the subjects sitting upright, the Cutiscan ${ }^{\circledR}$ probe was placed against the skin of the middle portion of the forearm volar surface. Care was taken to select regions free of hair and desquamation, which would negatively affect the analysis. A negative

\section{Introdução}

A pele é o maior órgão do corpo humano, exibindo conhecidas propriedades viscoelásticas que lhe permitem sofrer deformação em praticamente todas as direcções, sem sofrer quebra. (1) As propriedades viscoelásticas cutâneas têm sido investigadas por uma variedade de metodologias ao longo dos anos. Quanto aos métodos de avaliação, podem ser incluídos em cinco classes, incluindo tracção, torção, recuo, impacto, e elevação (por sucção), tendo este último recebido maior interesse nas últimas décadas. Em relação aos dispositivos de medição mais utilizados, o Cutometer ${ }^{\circledR}$ opera através de uma sucção da pele sendo o deslocamento cutâneo subsequente avaliado por um sistema óptico, enquanto o Reviscometer ${ }^{\circledR}$ quantifica o tempo de ressonância das vibrações transmitidas pela pele. Ambos estes dispositivos sofrem da mesma desvantagem que é a gama limitada de ângulos que são capazes de quantificar (2). O dispositivo Cutiscan ${ }^{\circledR}$ CS 100, introduzido recentemente, tem por objectivo modernizar a quantificação da viscoelasticidade, permitindo a sua quantificação simultânea ao longo de 360 ângulos, gravando-a em vídeo. Esta gravação em vídeo constitui uma sequência de fotografias ampliadas da superfície da pele, que apresentam uma morfologia complexa, irregular e com múltiplos padrões, constituindo assim um bom candidato para análise de textura (AT). A AT é uma ferramenta analítica de quantificação das características de uma imagem em escala de cinza texturalmente rica e tem sido aplicada a imagens médicas com a finalidade de melhorar a capacidade de diagnóstico, uma vez que a avaliação humana é demorada e propensa a erros de interpretação (3). Até agora, a quantificação dos parâmetros de Cutiscan ${ }^{\circledR}$ foi realizada a partir da análise de representações $2 \mathrm{D}$ e $3 \mathrm{D}$ da viscoelasticidade $(2,4)$. Apesar do seu enorme potencial o Cutiscan ${ }^{\circledR}$ permanece ainda pouco explorado em termos de instrumentação analítica, o que dificulta a sua divulgação. O nosso objetivo foi a exploração da AT de vídeos de deslocamento cutâneo feitos com Cutiscan ${ }^{\circledR}$ como uma ferramenta analítica para quantificação da viscoelasticidade cutânea.

\section{Materiais e métodos}

Dez indivíduos caucasianos do sexo feminino com pele saudável $(24,5 \pm 6,2$ anos) participaram neste estudo depois de dar o seu consentimento informado por escrito. Com os sujeitos sentado na posição vertical, a sonda de Cutiscan ${ }^{\circledR}$ foi colocada em contacto com a pele ao nível da porção média da superfície palmar do antebraço. 
suction pressure of 400 mbar was applied for 2 seconds, within a protocol totaling of 3 seconds - baseline ( 0.0 $-0.50 \mathrm{~s})$, suction $(0.50-2.50 \mathrm{~s})$ and recovery $(2.50-$ $3.00 \mathrm{~s}$ ), which was recorded on video by the device. Skin displacement videos $(1280 \times 1024$ resolution $)$ were imported to Matlab $^{\circledR}$ (Mathworks, USA) and decomposed into their individual frames. During suction the skin is pulled towards the probe camera, and the corresponding height of displacement $\left(\mathrm{h}_{\text {disp }}\right)$ is measured in terms of pixels (px) for each of the $360^{\circ}$ degrees, with the device firmware producing a standard viscoelasticity curve. For the extraction of textural parameters, a squared region of interest (ROI) was selected in the center of each video frame (see Figure 1A), which was subsequently transformed into a gray-level co-occurrence matrix (GLCM) by the examination of the spatial relationship of pixels. Based on this GLCM the calculation of the following textural parameters $(5,6)$ from a built-in algorithm was performed:

Contrast - the measure of the intensity contrast between a pixel and its neighbor over the whole image

Correlation - the correlation between adjacent pixels over the entire image.

Energy - returns the sum of squared elements in the GLCM

Homogeneity - the measure of the closeness of the distribution of elements in the GLCM to the GLCM diagonal

Entropy - the measure of randomness which can be used to characterize the texture of the input image.

The frames corresponding to three phases (baseline, suction, recovery) of skin displacement were selected and the textural parameters were calculated for each phase and statistically compared using the Wilcoxon signed-rank test $(\mathrm{p}<0.05)$.
Foi tido cuidado para selecionar apenas regiões livres de pêlo e de descamação, que afetariam negativamente a análise. Foi aplicada uma pressão negativa de sucção de 400 mbar durante 2 segundos, para um total de 3 segundos de protocolo - basal $(0,0-0.50 \mathrm{~s})$, sucção $(0,50$ - 2.50s) e recuperação $(2,50-3.00 \mathrm{~s})$, que foi gravado em vídeo pelo dispositivo. Os vídeos de deslocamento cutâneo (resolução de $1280 \times 1024$ ) foram importados para o Matlab $^{\circledR}$ (Mathworks, EUA) e decompostos nas suas imagens individuais. Durante a sucção a pele é puxada contra a câmara que está montada na sonda, e é medida a altura correspondente do deslocamento $\left(\mathrm{h}_{\text {disp }}\right)$ em termos de pixels (px) para cada um dos 360 graus, sendo produzida pelo software dedicado do dispositivo uma curva padrão de viscoelasticidade. Para efeitos de extracção dos parâmetros de textura, foi selecionada uma região de interesse $(\mathrm{RI})$ de formato quadrangular no centro de cada imagem do vídeo (ver Figura 1A), que foi subsequentemente transformada numa matriz de co-ocorrência (MCO) em de escala de cinza pela avaliação da relação espacial entre os pixels. Com base nesta $\mathrm{MCO}$ foi feito o cálculo dos seguintes parâmetros texturais $(5,6)$ a partir de um algortimo de raíz do software:

Contraste - mede o contraste de intensidade entre um pixel e seu vizinho ao longo de toda a imagem

Correlação - mede a correlação entre os pixels adjacentes ao longo de toda a imagem

Energia - devolve a soma de elementos quadrados na $\mathrm{MCO}$

Homogeneidade - mede a proximidade da distribuição de elementos na MCO à diagnonal da $\mathrm{MCO}$

Entropia - mede a aleatoriedade e pode ser usada para caracterizar a textura da imagem inicial

Foram selecionadas imagens correspondentes às três fases (basal, sucção, recuperação) do deslocamento cutâneo, calculando-se os parâmetros texturais para
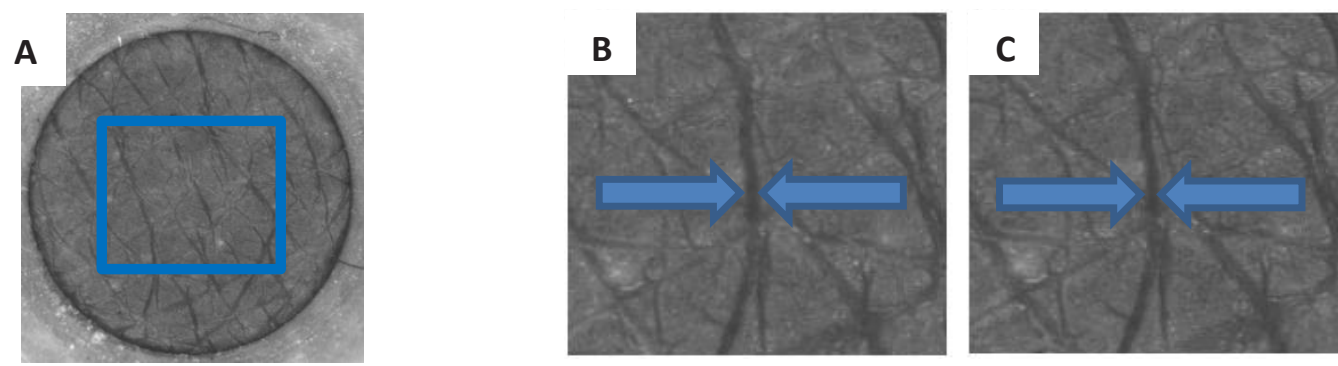

Figure 1/ Figura 1 - Forearm skin photo taken with CutiScan ${ }^{\circledR}$ camera, with a superimposed ROI (A); amplification of the forearm skin photo highlighting the furrow width during baseline (B) and during suction (C). Data from a 32 y.o. subject./ Fotografia da pele do antebraço obtida com a câmara do Cutiscan ${ }^{\circledR}$ com uma região de interesse sobreposta (A); ampliação da foto da pele salientando a largura do sulco durante a fase basal (B) e durante a sucção (C). Dados de uma voluntária de 32 anos. 


\section{Results and Discussion}

Figure 2 shows the time evolution of the mean $\mathrm{h}_{\text {disp }}$ and mean textural parameters during skin displacement following the suction challenge, which are presented for each phase on Table 1. cada fase, sendo comparados estatisticamente com o teste de Wilcoxon $(\mathrm{p}<0.05)$.

\section{Resultados e discussão}

Table 1/ Tabela 1 - Mean and standard deviation (sd) of the height of displacement $\left(\mathrm{h}_{\text {disp }}\right)$ and of the textural parameters in each phase of the suction protocol. Statistical comparison to baseline is presented $(*-p<0.05)$./ Média e desvio-padrão $(\mathrm{dp})$ da altura de deslocamento $\left(\mathrm{h}_{\text {disp }}\right)$ e dos parâmetros texturais em cada fase do protocolo de sucção. É apresentada a comparação estatística com a fase basal $(*-\mathrm{p}<0.05)$.

\begin{tabular}{|c|c|c|c|c|}
\hline Parameter / Pa। & metro & Baseline / Basal & Suction / Sucção & Recovery / Recuperação \\
\hline \multirow{3}{*}{$\mathbf{h}_{\text {disp }}$} & $\overline{\mathbf{x}}$ & 30.9 & 66.9 & 36.5 \\
\hline & $s d / d p$ & 10.2 & 14.1 & 13.0 \\
\hline & p & - & $0.028 *$ & 0.463 \\
\hline \multirow{3}{*}{$\begin{array}{l}\text { Entropy / } \\
\text { Entropia }\end{array}$} & $\overline{\mathbf{x}}$ & 5.130 & 5.171 & 5.134 \\
\hline & $s d / d p$ & 0.180 & 0.176 & 0.156 \\
\hline & p & - & $0.036^{*}$ & $0.028^{*}$ \\
\hline \multirow{3}{*}{$\begin{array}{l}\text { Contrast / } \\
\text { Contraste }\end{array}$} & $\overline{\mathbf{x}}$ & 0.057 & 0.064 & 0.055 \\
\hline & $s d / d p$ & 0.021 & 0.018 & 0.020 \\
\hline & p & - & 0.053 & 0.257 \\
\hline \multirow{3}{*}{$\begin{array}{c}\text { Correlation / } \\
\text { Correlação }\end{array}$} & $\overline{\mathbf{x}}$ & 0.689 & 0.706 & 0.703 \\
\hline & $s d / d p$ & 0.057 & 0.052 & 0.058 \\
\hline & $p$ & - & $0.018^{*}$ & $0.042^{*}$ \\
\hline \multirow{3}{*}{ Energy / Energia } & $\overline{\mathbf{x}}$ & 0.760 & 0.721 & 0.752 \\
\hline & $s d / d p$ & 0.113 & 0.105 & 0.138 \\
\hline & P & - & $0.049 *$ & 0.075 \\
\hline \multirow{3}{*}{$\begin{array}{l}\text { Homogeneity / } \\
\text { Homogeneidade }\end{array}$} & $\overline{\mathbf{x}}$ & 0.972 & 0.968 & 0.972 \\
\hline & $s d / d p$ & 0.011 & 0.009 & 0.010 \\
\hline & p & - & 0.180 & 0.157 \\
\hline
\end{tabular}

$\mathrm{h}_{\text {disp }}$ increased and reached a maximum at $1.00 \mathrm{~s}$, followed by a plateau phase until $1.50 \mathrm{~s}$ and finally by a decrease until $3.00 \mathrm{~s} . \mathrm{h}_{\text {disp }}$ increase was found to be statistically significant relative to baseline $(p=0.028)$, while no difference was noted during recovery, suggesting a mechanical recovery. A more irregular profile was observed for the textural parameters. Shortly after the $0.50 \mathrm{~s}$ mark, a sharp change was noted for all parameters, marking the immediate skin response to the application of suction. With the sustaining of suction, parameters did not attain a plateau phase, but a rather irregular evolution of the parameters was noted. This irregularity likely reflects skin anisotropy, on the one hand, and, on the other, the overall textural complexity of the skin lattice. The magnitude of all parameters changed during the suction phase, with some changing in the same direction that of $\mathrm{h}_{\text {disp }}$, some in the opposite direction. During suction skin is deformed towards the
A Figura 2 mostra a evolução temporal da $h_{\text {disp }}$ média e do valor médio dos parâmetros de textura durante o deslocamento cutâneao a seguir à sucção, que se apresentam por cada fase na Tabela 1 .

$\mathrm{A} \mathrm{h}_{\text {disp }}$ aumentou tendo alcançado um máximo aos $1.00 \mathrm{~s}$, seguindo-se uma fase de plateau até aos $1.50 \mathrm{~s}$ e, finalmente, uma diminuição até aos $3.00 \mathrm{~s}$. O aumento de $h_{\text {disp }}$ foi estatisticamente significativo em relação à fase basal $(\mathrm{p}=0.028)$, enquanto que durante a recuperação não foi observada nenhuma diferença face à fase basal, o que sugere uma recuperação mecânica. Para os parâmetros texturais foi observado um perfil mais irregular. Logo após os $0.50 \mathrm{~s}$, foi observada uma mudança em todos os parâmetros, o que assinala a resposta imediata da pele perante a aplicação da sucção. Com a manutenção da sucção, os parâmetros não atingiram uma fase de plateau, tendo-se observado uma evolução bastante irregular. Esta irregularidade reflete provavel- 
center of the field, with the consequent narrowing of the furrows and rising of the ridges (see Figure 2B-C), which changes overall skin lattice morphology, with an obvious translation in terms of its textural parameters. Entropy, contrast, and correlation increased irregularly until 2.00s and then decreased until 3.00s. The increase of entropy and correlation during suction was found to be statistically significant $(\mathrm{p}=0.036$ and $\mathrm{p}=0.018$, respectively), and remained significantly elevated after suction ended ( $\mathrm{p}=0.028$ and $\mathrm{p}=0.042$, respectively). Contrast also increased with suction, but without statistical significance. Energy and homogeneity, however, decreased during suction but only with statistical significance for the former $(\mathrm{p}=0.049)$. During recovery, only entropy and correlation showed statistical differences regarding baseline ( $\mathrm{p}=0.028$ and $\mathrm{p}=0.042$, respectively), suggesting that skin did not fully recover in these conditions. Displaced skin is bent in many different directions, which adds complexity to its surface architecture and increases textural entropy. With furrow narrowing, the images become more homogenous, especially towards the center, which explains the resulting reduction in homogeneity and the increase in overall pixel frame correlation. The narrowing of furrows further increased mente, por um lado, a anisotropia da pele e, por outro lado, a complexidade textural geral da estrutura da pele. Todos os parâmetros sofreram uma alteração de magnitude durante a fase de sucção, alguns no mesmo sentido de $\mathrm{h}_{\text {disp }}$, outros no sentido contrário. Durante a sucção a pele é deformada em direcção ao centro do campo, verificando-se um consequente estreitamento dos sulcos e aumento das papilas (Figura 2B-C), com uma alteração da morfologia global da estrutura cutânea, com uma tradução evidente em termos dos seus parâmetros texturais. A entropia, contraste e correlação aumentaram irregularmente até aos $2.00 \mathrm{~s}$, e diminuíram de seguida até aos $3.00 \mathrm{~s}$. O aumento da entropia e correlação durante a sucção verificou-se ser estatisticamente significativo ( $\mathrm{p}=0.036$ e $\mathrm{p}=0.018$, respectivamente), mantendo-se significativamente elevados após o fim da sucção ( $p=0.028$ e $p=0.042$, respectivamente). O contraste aumentou também com a sucção, mas sem significância estatística. A energia e a homogeneidade, no entanto, diminuiram com a sucção, mas apenas com significância estatística no primeiro caso $(p=0.049)$. Durante a recuperação, apenas a entropia e correlação mostraram diferenças estatísticas em relação à fase basal $(p=0.028$ e $p=0.042$, respectivamente), sugerindo

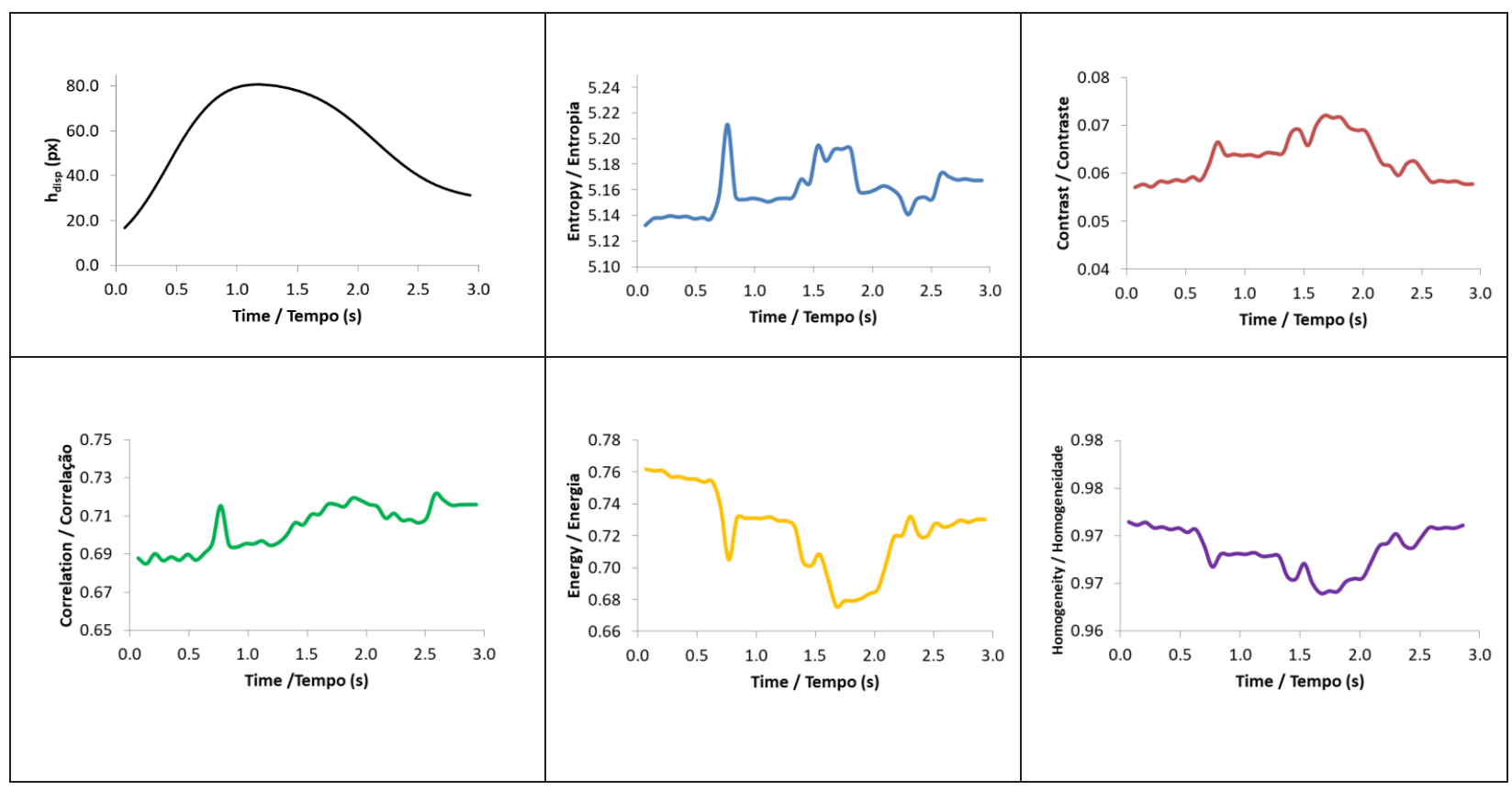

Figure 2/ Figura 2 - Mean time evolution (baseline: $0.0-0.5 \mathrm{~s}$; suction: $0.5-2.5 \mathrm{~s}$; recovery: 2.5-3.0s) of $\mathrm{h}_{\text {disp }}$ (black) and of the textural parameters (entropy - blue; contrast - red; correlation - green; energy - yellow; homogeneity - purple)/ Evolução temporal média (basal: 0.0-0.5s; sucção: $0.5-2.5 \mathrm{~s}$; recuperação: $2.5-3.0 \mathrm{~s}$ da $\mathrm{h}_{\text {disp }}$ (preto) e dos parâmetros texturais (entropia - azul; contraste - vermelho; correlação - verde; energia - amarelo; homogeneidade - roxo) 
the definition of the individual ridges, which justifies the increase in contrast. Given that furrows are darker areas while ridges are brighter, it is logical that energy should increase during suction. Although texture analysis has been employed in dermatoscopy for diagnostic purposes (7-9), to our knowledge this is the first time that it has been employed to quantify skin viscoelasticity. In the present conditions, entropy and correlation showed higher sensitivity, while contrast and homogeneity showed the lowest sensitivity. Texture analysis presented contradictory results regarding the mechanical recovery to suction, as entropy and correlation suggested that a full recovery was not attained by the end of the challenge, while energy supported the opposite. Further studies should be performed in different experimental conditions to improve the robustness of the proposed methodology.

\section{Conclusion}

These results seem to confirm the usefulness of texture analysis for the purposes of skin viscoelasticity quantification based on skin displacement videos, which justifies further developments.

\section{Acknowledgements}

The authors wish to acknowledge the FCT-IP project UID/DTP/04567/2016 for the funding to carry out this work. The authors would also like to express their thanks to the subjects that participated in this study.

\section{Conflict of Interests}

All authors declared no conflict of interests. que, nestas condições, a pele não recuperou totalmente. A pele que sofreu deslocamento é dobrada em muitas direções diferentes, o que acrescenta complexidade à sua arquitetura superficial, aumentando a entropia textural. Com o estreitamento dos sulcos, as imagens tornam-se mais homogéneas, especialmente próximo do centro, o que explica a resultante diminuição na homogeneidade e o aumento da correlação geral da imagem em termos de pixels. $\mathrm{O}$ estreitamento dos sulcos aumentou ainda mais a definição das cristas individuais, o que justifica o aumento do contraste. Dado que os sulcos são áreas mais escuras e as cristas mais brilhantes, é lógico que a energia deve aumentar durante a sucção. Embora a AT tenha sido usada em dermatoscopia para fins de diagnóstico (7-9), de acordo com o nosso conhecimento, esta é a primeira vez em que é usada para quantificar a viscoelasticidade da pele. Nas presentes condições, a entropia e correlação mostraram mais uma sensibilidade mais elevada, enquanto que o contraste e a homogeneidade mostraram uma sensibilidade reduzida. A AT revelou resultados contraditórios em termos de recuperação mecânica à sucção, sugerindo a entropia e a correlação a ausência de uma recuperação completa no final do teste, enquanto que a energia apoia uma conclusão oposta. Estudos adicionais deverão ser realizado em diferentes condições experimentais para melhorar a robustez do método proposto.

\section{Conclusão}

Estes resultados parecem confirmar a utilidade da análise de textura para fins de quantificação da viscoelasticidade cutânea com base em vídeos de deslocamento, justificando desenvolvimentos futuros.

\section{Agradecimentos}

Os autores querem agradecer ao projecto FCT-IP/DTP $/ 04567 / 2016$ pelo financiamento para realizar este trabalho. Os autores gostariam também de expressar os seus agradecimentos aos voluntários pela sua participação neste estudo.

\section{Conflito de Interesses}

Os autores não declararam qualquer conflito de interesses. 


\section{References/ Referências}

1. Ruvolo Jr EC, Stamatas GN, Kollias N. Skin viscoelasticity displays site-and age-dependent angular anisotropy. Skin Pharmacology and Physiology. 2007;20(6):313-21.

2. Rosado C, Antunes F, Barbosa R, Fernando R, Estudante M, Silva HN, Rodrigues LM. About the in vivo quantitation of skin anisotropy. Skin Research and Technology. 2017; 23(3):429-36.

3. Larroza A, Bodí V, Moratal D. Texture analysis in magnetic resonance imaging: review and considerations for future applications. Assessment of cellular and organ function and dysfunction using direct and derived MRI methodologies. 2016; 26:75-106.

4. Silva H, Rego F, Rosado C, Rodrigues LM. Novel 3D “ active ” representations of skin biomechanics. Biomedical and Biopharmaceutical Research. 2016; 13(2): 219-227.https://doi.org/10.19277/bbr.13.2.140

5. World Health Organization. Handbook for good clinical research practice (GCP): guidance for implementation.

6. World Medical Association. Declaration of Helsinki. Ethical Principles for Medical Research Involving Human Subjects. JAMA. 2013;310(20):21912194. doi:10.1001/jama.2013.281053

7. Yusof NS, Dewi DE, Faudzi AA, Salih NM, Bakar NA, Hamid HA. Ultrasound imaging characterization on tissue mimicking materials for cardiac tissue phantom: Texture analysis perspective. Malaysian Journal of Fundamental and Applied Sciences. 2017; 17;13(4-2):501-8.

8. Gonzalez RC, Eddins SL, Woods RE. Digital image publishing using MATLAB. Prentice Hall; 2004.

9. Barata C, Celebi ME, Marques JS. A survey of feature extraction in dermoscopy image analysis of skin cancer. IEEE journal of biomedical and health informatics. 2018 Jun 11;23(3):1096-109. 